TABLE I-Comparison of Groups 1 and 2. Values are Means $\pm S . D$.

\begin{tabular}{|c|c|c|c|c|c|}
\hline & $\begin{array}{l}\text { No. of } \\
\text { Patients }\end{array}$ & $\begin{array}{c}\text { Primidone } \\
\text { Dose } \\
(\mathrm{mg} / \mathrm{kg})\end{array}$ & $\begin{array}{c}\underset{\text { Primidone }}{\text { Serum }} \\
(\mu \mathrm{mol} / \mathrm{l})\end{array}$ & $\begin{array}{c}\text { Serum } \\
\text { Pheno- } \\
\text { barbitone } \\
(\mu \mathrm{mol} / 1)\end{array}$ & $\begin{array}{l}\text { Pheno- } \\
\text { barbitone: } \\
\text { Primidone }\end{array}$ \\
\hline $\begin{array}{l}\text { Group } 1 \\
\text { Group } 2\end{array}$ & $\begin{array}{l}12 \\
50\end{array}$ & $\begin{array}{l}12 \cdot 6 \pm 1 \cdot 9 \\
12 \cdot 2 \pm 0.6\end{array}$ & $\begin{array}{l}54 \cdot 1 \pm 6 \cdot 9 \\
52 \cdot 2 \pm 2 \cdot 8\end{array}$ & $\begin{aligned} 83.5 & \pm 15 \cdot 9 \\
101.6 & \pm 6.0\end{aligned}$ & $\begin{array}{l}1 \cdot 57 \pm 0 \cdot 17 \\
2 \cdot 20 \pm 0 \cdot 12^{*}\end{array}$ \\
\hline
\end{tabular}

*P $<0.02$.

Conversion: SI to Traditional Units

Primidone: $1 \mu \mathrm{mol} / 1 \approx 0.218 \mathrm{mg} / 1$.

Phenobarbitone: $1 \mu \mathrm{mol} / 1 \approx 0 \cdot 232 \mathrm{mg} / \mathrm{l}$.

\section{Discussion}

Our data suggest that phenytoin has an effect on the metabolism of primidone which results in relatively higher levels of phenobarbitone derived from primidone. This effect is related partly to the serum level of phenytoin. There was no apparent influence on the unmetabolized primidone levels. Similar findings have recently been reported by Fincham et al.,4 who, however, found no relation between the phenobarbitone: primidone ratio and serum phenytoin.

Fincham et al. ${ }^{4}$ suggest that phenytoin induces the liver enzyme system responsible for the oxidation of primidone to phenobarbitone, but there are other possible explanations. Despite great interest in the effects of phenobarbitone on phenytoin metabolism ${ }^{1}$ there has been little study of the effect of phenytoin on phenobarbitone. Both clinically ${ }^{5}$ and experimentally ${ }^{6}$ phenytoin may raise serum levels of phenobarbitone. Rizzo et al. ${ }^{\circ}$ suggested that phenytoin may competitively inhibit the metabolism of phenobarbitone or impair its renal excretion. Such mechanisms might also explain the effect of phenytoin on phenobarbitone derived from primidone.

The combination of phenytoin and primidone is commonly encountered in clinical practice; at King's-Maudsley seizure clinic a combination of phenytoin and primidone, sometimes in association with other drugs, was being taken by $119(47 \%)$ out of 253 patients. This was at least twice as common as any other anticonvulsant combination (table II). Thus we suspect that the interaction of phenytoin and primidone may be important clinically in relation to both seizure control and toxicity.

TABLE II-Anticonvulsant Drugs Taken by 253 Patients Attending King'sMaudsley Seizure Clinic

\begin{tabular}{|c|c|c|c|}
\hline - & $\begin{array}{r}\text { No. (\%) of } \\
\text { Patients } \\
4(1 \cdot 6)\end{array}$ & $\mathbf{N}$ & $\begin{array}{l}\text { No. (\%) of } \\
\text { Patients }\end{array}$ \\
\hline $\begin{array}{l}\text { Phenobarbitone and other } \\
\text { drugs* } \\
\text { Primidone } \\
\text { Primidone and other drugs } \\
\text { Phenytoin } \\
\text { Phenytoin and other drugs } \\
\text { Phenobarbitone and }\end{array}$ & $\begin{array}{r}4(1 \cdot 6) \\
8(3 \cdot 2) \\
14(5 \cdot 5) \\
26(10 \cdot 3) \\
18(7 \cdot 1)\end{array}$ & $\begin{array}{l}\text { other drugs } \\
\text { Primidone, phenytoin, and } \\
\text { phenobarbitone } \\
\text { Primidone, phenytoin, pheno- } \\
\text { barbitone, and other drugs } \\
\text { Phenobarbitone and } \\
\text { nrimidone }\end{array}$ & $\begin{array}{r}42(16.6) \\
13(5 \cdot 1) \\
-\quad 6(2.4)\end{array}$ \\
\hline $\begin{array}{l}\text { Phenobarbitone and } \\
\text { phenytoin } \\
\text { Phenobarbitone, phenytoin, } \\
\text { and other drugs } \\
\text { Primidone and phenytoin }\end{array}$ & $\begin{array}{r}28(11 \cdot 1) \\
20(7 \cdot 9) \\
58(22 \cdot 9)\end{array}$ & $\begin{array}{l}\text { primidone } \\
\text { Phenobarbitone, primidone, } \\
\text { and other drugs } \\
\text { Other drugs }\end{array}$ & $\begin{array}{l}4(1 \cdot 6) \\
4(1 \cdot 6) \\
4(1 \cdot 6)\end{array}$ \\
\hline
\end{tabular}

*Other drugs included ethosuximide, carbamazepine, diazepam, sulthiame, and pheneturide.

We thank Mr. L. Vydelingum for technical help, and the Medical Research Council and Ciba-Geigy for financial support.

Requests for reprints should be addressed to Dr. E. H. Reynolds, University Department of Neurology, Institute of Psychiatry, De Crespigny Park, London SE5 8AF.

\section{References}

${ }^{1}$ Kutt, H., in Antiepileptic Drugs, ed. D. M. Woodbury, J. K. Penry, and R. P. Schmidt, p. 169. New York, Raven Press, 1972.

2 Gallagher, B. B., and Baumel, I. P., in Antiepileptic Drugs, ed. D. M. Woodbury, J. K. Penry, and R. P. Schmidt, p. 361. New York, Raven Press, 1972.

3 Kupferberg, H. J., Clinica Chimica Acta, 1970, 29, 283.

4 Fincham, R. W., Schottelius, D. D., and Sahs, A. L., Archives of Neurology, 1974, 30, 259 .

${ }^{5}$ Morselli, P. L., Rizzo, M., and Garattini, S., Annals of the New York Academy of Sciences, 1971, 179, 88.

${ }^{6}$ Rizzo, M., Morselli, P. L., and Garattini, S., Biochemical Pharmacology, $1972,21,449$.

\title{
Cardiac Tamponade and Central Venous Catheters
}

\author{
M. J. GREENALL， R. W. BLEWITT， M. J. MCMAHON
}

British Medical fournal, 1975, 2, 595-597

\section{Summary}

An analysis of the reports on 16 patients who developed cardiac tamponade, complicating the use of central venous catheters, showed that 14 died. The two survivors were treated by removal of the catheter and needle aspiration of the pericardial fluid. Some patients complained of warning symptoms such as nausea, pain, and dyspnoea, and the combination of tachycardia, hypotension, and raised venous pressure was common. We suggest that awareness of the hazard, radiographic visualization of the catheter tip, and expeditious treatment would reduce the mortality.

\footnotetext{
University Departments of Surgery and Pathology, The General Infirmary, Leeds 1

M. J. GREENALL, B.sC., M.B., Research Assistant

R. W. BLEWITT, B.SC., M.B., Lecturer in Pathology

M. J. MCMAHON, PH.D., F.R.C.s., Lecturer in Surgery
}

\begin{abstract}
Introduction
Wherever it lies, the tip of an intravenous catheter may perforate the vein wall. Perforation is particularly hazardous when the central veins are catheterized and may lead to hydromediastinum, hydrothorax, or, more catastrophically, cardiac tamponade. In some cases-for example, during cardiac catheterization-it is necessary to pass the tip of the catheter into the heart itself and tamponade is an accepted complication, but for most purposes of central venous monitoring and feeding a more peripheral site can be accepted. Nevertheless, cardiac tamponade continues to be reported. From reported observations and our own experience of a case, which is described below, we suggest precautions to prevent tamponade and describe how to recognize it clinically and institute emergency treatment.
\end{abstract}

\section{Case History}

A 35-year-old man presented with a severe dumping syndrome and diarrhoea after truncal vagotomy and pyloroplasty. Conservative measures were of no avail and two reversed jejunal loops were interposed, one between the stomach and duodenum and the other $100 \mathrm{~cm}$ distal to the ligament of Treitz. Gastric aspiration produced large volumes of fluid postoperatively and barium-meal examination on the 
fifth day showed hold-up and a small leak at the distal anastomosis of the upper reversed segment. Thus we decided to institute parenteral feeding.

A $1.65-\mathrm{mm}$ (O.D.) polyvinyl chloride (PVC) catheter (Abbott "Drum") was introduced through a cut-down in the right brachial vein. The catheter tip was visualized radiographically in the upper superior vena cava. A feeding regimen of amino-acid, fructose, and fat was begun, but on the tenth postoperative day the catheter was removed because of a crack in the Luer connector. A further catheter was then inserted through a left brachial cut-down. Only small-calibre veins were found and a 1.02-mm (O.D.) nylon catheter (Portex) was introduced, its tip being estimated to be in a similar position to that of the PVC catheter. The tip was not visualized on the chest radiograph taken after introduction as it was radiolucent, but no other abnormality was found. The catheter was secured with a stitch at its entry site. For the next eight days the catheter functioned satisfactorily, the patient enjoyed good general health, and the volume of the aspirate began to diminish.

In the early hours of the eighteenth postoperative day the patient complained of transient epigastric pain, nausea, and dyspnoea. He was examined by a resident, who noticed a tachycardia of $120 / \mathrm{min}$ for which he could find no explanation, and placed under constant observation. After about half an hour, during which the pulse rate increased slightly, he collapsed and died despite attempts at resuscitation. His neck veins were noticed to be engorged.

At necropsy, before which the catheter had been withdrawn, the stomach was empty and all anastomoses were healed. The pericardium was distended with $400 \mathrm{ml}$ of opaque yellow fluid, the constitution of which was consistent with the parenteral diet. A small speck of thrombus was found on the wall of the right brachiocephalic vein close to the origin of the superior vena cava but no perforation was found in the central veins or heart. There was oedema of the anterior mediastinum around the superior vena cava, and the oedema fluid had similar characteristics to that removed from the pericardium.

\section{Discussion}

Cardiac tamponade is a well recognized complication of cardiac catheterization and has occurred after embolization of a fragment of an intravenous catheter. We were concerned with intact central venous monitoring or feeding catheters, and the details of 15 cases reported, as well as our own, are given in the table. The increasing use of central venous catheterization techniques has brought in its wake a considerable rate of complications, but none more serious than tamponade, which resulted in death in 14 of the 16 patients.

In nine cases perforation of the right side of the heart was identified. In no instance had the position of the catheter tip been visualized radiographically. There was one confirmed puncture of the superior vena cava, ${ }^{1}$ and the presence of fluid containing fat particles around the superior vena cava suggested this as the mechanism in our case, but in the remainder the puncture site was not identified.

Clearly, radiographic visualization with either a radiopaque catheter or the injection of contrast medium is essential to obtain a correct catheter position. Most catheters will function satisfactorily for both monitoring and feeding with the tip lying at or just proximal to the origin of the superior vena cava-that is, above its pericardial reflections. We suggest that the tip should lie no more than $2 \mathrm{~cm}$ below a line joining the lower surfaces of the ends of the clavicles on a posteroanterior chest radiograph (see fig.). A secure anchoring suture will prevent movement of the catheter at the puncture site, but shoulder movement may cause considerable changes in the position of the tip of the catheter when it has been introduced through an arm vein. When this is the case, therefore, we recommend that the check radiograph be taken with the arm abducted to $90^{\circ}$, the patient being advised not to raise it beyond that level.

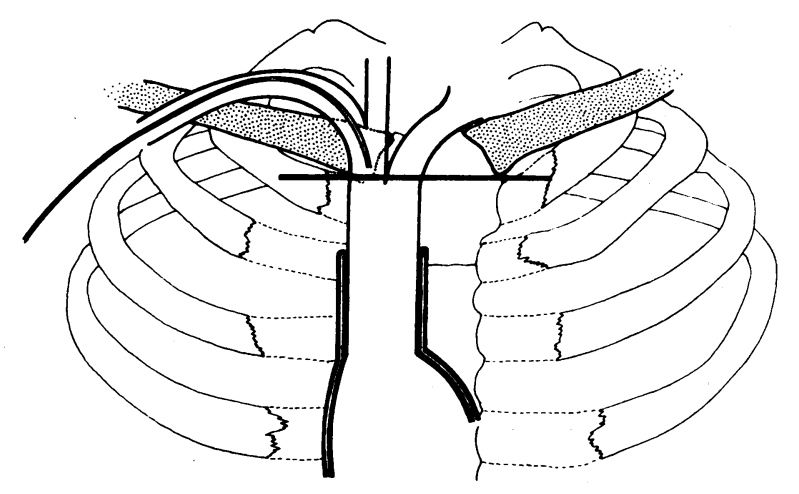

Outline diagram of central veins superimposed on skeletal appearance of posteroanterior chest radiograph. Line is drawn below lower surface of each clavicle (shaded), and we suggest that tip of catheter should lie no more than $2 \mathrm{~cm}$ below this. Heavy lines represent pericardial reflections around superior vena cava.

Intravenous catheters vary in their stiffness, ${ }^{2}$ and soft PVC or Silastic may be less dangerous. The practice of sharpening the tip to facilitate introduction has been condemned.

In seven cases tamponade appeared within 24 hours of introducing the catheter, and probably in many of these the pericardium was entered at or shortly after the time of insertion. There should be complete satisfaction that free flow is obtained in both directions; failure to aspirate blood freely may mean that the tip of the catheter is already extravascular or pressed against the vein wall and likely to penetrate it. It is probably wise to use only an electrolyte solution in the first 12 hours before proceeding with intravenous nutrition.

Some patients complained of nausea, epigastric discomfort, and dyspnoea, and confusion was noticed in three. Tachycardia was recorded in seven cases, hypotension in nine, and raised jugular or central venous pressure in nine. Most patients with central venous lines can be kept under close supervision, and staff should be alerted to the possible significance of these features.

In most cases a clinical diagnosis of tamponade could probably have been made had the medical attendants been aware of the

Comparison of 16 Cases of Cardiac Tamponade Complicating Use of Intact Central Venous Catheters

\begin{tabular}{|c|c|c|c|c|c|c|c|c|}
\hline Author & Puncture Site & $\begin{array}{l}\text { Radiographic } \\
\text { Visualization }\end{array}$ & $\begin{array}{c}\text { Volume of } \\
\text { Pericardial } \\
\text { Fluid } \\
\text { (ml) }\end{array}$ & $\begin{array}{l}\text { Time Between } \\
\text { Insertion and } \\
\text { Tamponade }\end{array}$ & Tachycardia & Hypotension & $\begin{array}{c}\text { Raised } \\
\text { Venous } \\
\text { Pressure }\end{array}$ & Outcome \\
\hline $\begin{array}{l}\text { Delfalque (1971) } \\
\text { Friedman and Jurgeleit }(1968)^{3} \\
\text { Burton et al. }(1968)^{4} \\
\text { Kline and Hofman }(1968)^{6} \\
\text { Thomas et al. }(1969)^{6} \\
\text { Brandt et al. }(1970)^{7} \\
\text { Fit ts et al. }(1970)^{8} \\
\text { Bowe et al. (1973) } \\
\text { Adar and Mozes }(1971)^{10} \\
\text { Homesley and Selenik }(1971)^{11} \\
\text { Dane and King }(1975)^{12} \\
\text { Present case }\end{array}$ & $\begin{array}{l}\text { Superior vena cava } \\
\text { Right atrium } \\
\text { Right atrium } \\
\text { Right atrium } \\
\text { Right ventricle } \\
\text { ? } \\
\text { ? } \\
\text { Right ventricle } \\
\text { ? } \\
\text { Right atrium } \\
\text { Right atrium } \\
\text { ? } \\
\text { Right atrium } \\
\text { ? } \\
\text { Right ventricle } \\
\text { ?Saperior vena cava }\end{array}$ & $\begin{array}{l}\text { No } \\
\text { No } \\
\text { No } \\
\text { No } \\
\text { No } \\
\text { No } \\
\text { Yes, right atrium } \\
\text { No } \\
\text { No } \\
\text { No } \\
\text { No } \\
\text { Yes, right atrium } \\
\text { No } \\
\text { No } \\
\text { No } \\
\text { No }\end{array}$ & $\begin{array}{r}500 \\
600 \\
400 \\
1000 \\
>200 \\
>250 \\
>500 \\
800 \\
>300 \\
600 \\
350 \\
535 \\
530 \\
>180 \\
400\end{array}$ & $\begin{aligned} 5 \text { Minutes } \\
8 \text { Days } \\
30 \text { Minutes } \\
1 \text { Hour } \\
30 \text { Minutes } \\
48 \text { Hours } \\
36 \text { Hours } \\
<12 \text { Hours } \\
<24 \text { Hours } \\
8 \text { Days } \\
6 \text { Hours } \\
3 \text { Days } \\
40 \text { Hours } \\
<2 \text { Days } \\
2 \text { Days } \\
8 \text { Days }\end{aligned}$ & $\begin{array}{c}+ \\
+ \\
+ \\
+ \\
+ \\
+ \\
\text { No } \\
+\end{array}$ & $\begin{array}{l}+ \\
+ \\
+ \\
+ \\
+ \\
+ \\
+ \\
+ \\
+ \\
+ \\
+\end{array}$ & $\begin{array}{l}+ \\
+ \\
+ \\
+ \\
+ \\
+ \\
+ \\
+ \\
+ \\
+\end{array}$ & $\begin{array}{l}\text { Death } \\
\text { Death } \\
\text { Death } \\
\text { Death } \\
\text { Death } \\
\text { Survival } \\
\text { Death } \\
\text { Death } \\
\text { Surviva } 1 \\
\text { Death } \\
\text { Death } \\
\text { Death } \\
\text { Death } \\
\text { Death } \\
\text { Death } \\
\text { Death }\end{array}$ \\
\hline
\end{tabular}


possibility, and there was usually enough time to aspirate the pericardial fluid. In only one case was there an appreciable amount of blood in the pericardial fluid, tamponade being due to the infusate in the remainder. In the two successes treatment consisted in removal of the catheter and needle aspiration of the fluid. We suggest that when a clinical diagnosis of tamponade is made treatment should be instituted without waiting for confirmation from radiographs, which may in any case be equivocal. Initially an attempt should be made to aspirate fluid through the catheter by attaching a syringe direct to its Luer connector. The aspiration of fluid other than blood supports the diagnosis; and when no more fluid can be withdrawn the catheter should be removed. No more action need be taken if the patient's condition is satisfactory. Continuing clinical deterioration or failure to obtain aspirate from the catheter are indications for urgent pericardial needle aspiration. We further suggest that a needle suitable for pericardial aspiration should be kept in the same room as patients with central venous catheters, that needle aspiration of the pericardial sac should be included in the routine resuscitation programme for cardiac arrest when a central venous catheter is in situ, and that fluid used in the resuscitation programme should not be administered through an existing central venous catheter without pulling it back at least $15 \mathrm{~cm}$.

\section{References}

1 Delfalque, R. J., Canadian Anaesthetists' Society fournal, 1971, 18, 681.

2 McMahon, M. J., British Medical fournal, 1973, 3, 353.

Friedman, B. A., and Jurgeleit, H. C., Fournal of the American Medical Association, 1968, 203, 1141 .

${ }^{4}$ Burton, J. J, Venecko, R., and Gross, M., Obstetrics and Gynecology, 1968, 32, 556 .

${ }^{5}$ Kline, I. K., and Hofman, W. I., Fournal of the American Medical Association, 1968, 206, 1974.

6 Thomas, C.' S., Carter, J. W., and Lowder, S. C., Archives of Surgery, $1969,98,217$.

'Brandt, R. L., et al., American fournal of Surgery, 1970, 119, 311.

${ }^{8}$ Fitts, C. T., et al., Fournal of Trauma, $1970,10,764$.

$\checkmark$ Bowe, D. K., et al., Archives of Surgery, 1973, 106, 868

10 Adar, R., and Mozes, M., British Medical fournal, 1971, 3, 746.

11 Homesley, H. D., and Selenik, J. S., American fournal of Obstetrics and Gynecology, 1971, 109, 1216 .

${ }^{12}$ Dane, T. E. B., and King, E. G., British fournal of Surgery, 1975, 62, 6.

\section{SHORT REPORTS}

\section{Minor Epidemic of Trichophyton rubrum}

Within two weeks three men in the same geriatric ward had an erythematous rash around the buttocks. In one the eruption had been present for several months, but the other two developed a similar rash within a few days of each other. All three were ideal candidates for a Candida infection as they were debilitated, intermittently incontinent, and had been on broad-spectrum antibiotics; one was a diabetic. They proved, however, to have a dermatophyte infection. They shared the use of a commode seat and as only their three names were written on the elastoplast stuck on the commode back rest, it suggested that the commode was responsible for the spread of infection. In a recent outbreak of dermatophytosis the commode seat was incriminated in the transmission of fungus. ${ }^{1}$

\section{Case Histories}

An 88-year-old diabetic hemiplegic developed an erythematous rash on his buttocks which failed to respond to fluorinated steroid ointment and Castellani's paint. He was intermittently incontinent and had had course of tetracycline. The non-irritating erythematous scaling rash extended from the buttocks to the perineum, thighs, and sacral region. Mycological examination confirmed the clinical diagnosis of dermatophyte infection of the buttocks and mild scaling in the toe clefts also proved to be fungal in origin.

A mildly demented 83-year-old intermittently incontinent hemiplegic A mildy demented 83-year-old intermittently incontinent hemiplegic, who had previously been on broad-spectrum antibiotics, developed a nonand scrotum. Mycological examination confirmed the dermatophyte infecand scrotum. Mycological examination confirmed

A 70-year-old demented, intermittently incontinent hemiplegic with prostatism, who had recently been on broad-spectrum antibiotics, developed an itchy, erythematous scaling rash on the buttocks, perineum, scrotum, thighs, and lower back. The dermatophyte infection was confirmed, but there was no evidence of fungus on the feet.

Mycological culture showed that all three men had Trichophyton rubrum infection on the buttocks; the first patient had T. rubrum in the toe cleft also, but the other two did not. They all cleared on griseofulvin systemically and local applications.

\section{Discussion}

T. rubrum infection usually affects the feet ${ }^{2}$ and hands; some think that if the trunk is affected it is secondary to infection of limbs. In these patients one man had T. rubrum on his feet with secondary spread to the buttocks and groins. Consequently he probably contaminated the commode seat with shreds of skin and was instrumental in transmitting the infection directly on to the buttocks of the other two men who shared the commode. Neves and Zavier, ${ }^{3}$ investigating the transmission of tinea cruris in a sanatorium, postulated that non- living objects (such as toilet seats) can act as vehicles, carrying fungi to the skin of others. When dermatophytes reach the skin of susceptible hosts they grow under favourable conditions-for instance, poor hygiene, increased sweating and secretions-and produce lesions. The cases under discussion comply with these criteria and the situation was aggravated by the trauma ${ }^{4}$ to the buttocks of excess pressure and products of incontinence. Pressure and incontinence are the most likely causes of an erythematous rash on the buttocks and groins of any long-term inpatient, but psoriasis, eczema, erythrasma, and fungal infections must be considered in the differential diagnosis. Monilia is the most common fungal infection of the perineum, but as these cases illustrate, a dermatophyte infection could quickly escalate into a minor epidemic.

\section{British Medical fournal, 1975, 1, 745. \\ ${ }^{2}$ Rosenthal, S. A., et al., Archives of Dermatology, 1967, 96, 51. \\ 3 Neves, H., and Xavier, N. C., British fournal of Dermatology, 1964, 76, 429. \\ 4 Baer, R. L., and Rosenthal, S. A., Fournal of the American Medical Asso-} ciation, 1966, 197, 1017.

Department of Dermatology, Royal South Hants Hospital, Fanshawe Street, Southampton

K. LIDDELL, M.B., M.R.C.P., Senior Registrar

\section{Treatment of Hypertriglyceridaemia after Renal Transplantation}

Hyperlipoproteinaemia, which is often associated with premature atherosclerosis, occurs in many patients after renal transplantation owing to an accumulation of very-low-density lipoproteins (type IV hyperlipidaemia). ${ }^{12}$ It is attributed to corticosteroid therapy, ${ }^{1}$ which through the increase of basal insulinaemia may stimulate the hepatic secretion of triglycerides. ${ }^{3}$ Since it is not apparently related to renal function or transplant age ${ }^{1}$ patients with successful transplants are exposed to a complication which per se or in combination with other conditions-arterial hypertension, glucose intolerance, arterial calcification, and hyperuricaemia, for example-predisposes to accelerated atherosclerosis.

A low calorie, low carbohydrate diet reduces the triglycerides to normal in most patients with essential type IV hyperlipidaemia, ${ }^{4}$ presumably by affecting the production of very-low-density lipoproteins and reducing the precursors of triglycerides. We therefore recommended such a diet for six adults with normal renal function 